\title{
Repentance and Subjective Well-being of Muslim College Students who Access Pornography: Self- control as a Moderator
}

\author{
Syafira Putri Ekayani ${ }^{1}$, Syarifah Nur Lathifah ${ }^{2}$, Veany Aprillia ${ }^{3}$, and Fuad Nashori ${ }^{4}$ \\ \{syafira15putri@gmail.com ${ }^{1}$, zubairsyarifah@gmail.com², veany29@gmail.com³, \\ fuadnashori@uii.ac.id $\left.{ }^{4}\right\}$
}

Faculty of Psychology and Social Cultural Sciences, Universitas Islam Indonesia, Jogjakarta ${ }^{1}$

\begin{abstract}
Based on a survey of 133 Muslim college students in Yogyakarta found 75,9\% of students had accessed cyber pornography. Islam has explicitly prohibits people from approaching pornography, this causes psychological conflicts in students because of differences in beliefs and actions, then causes anxiety as the characteristics of low subjective well-being. Religion is one of the factors that improve subjective wellbeing. Islam commands people to repent. Self-control helps a person refrain from making the same mistakes. This recent study used a correlational method and multiple regression analysis. The subject of this study was 102 bachelor students at Islamic universities in Yogyakarta. Measurements used the SWLS $(a=0,819)$, PANAS: Positive Affect $(\mathrm{a}=0,797)$ and Negative Affect $(\mathrm{a}=0,877)$, Brief Self-control Scale $(\mathrm{a}=0,692)$, and Repentance Scale $(\mathrm{a}=0,841)$. The results of the data analysis using Pearson Correlation Bivariate shows the correlation between Repentance and Self-control $r=0,505$ $\operatorname{sig}(\mathrm{p})<0,001$; Repentance and Subjective well-being $\mathrm{r}=0,366 \operatorname{sig}(\mathrm{p})<0,001$; Self-control and Subjective well-being $\mathrm{r}=0,574 \operatorname{sig}(\mathrm{p})<0,001$. There is a correlation between Repentance, Self-control, and Subjective Well-being of students at Islamic universities in Yogyakarta. Multiple regression analyses self-control as a moderator. The result was self-control strengthens the relationship between repentance and subjective well-being. The research hypothesis was accepted.
\end{abstract}

Keywords: Repentance, subjective well-being, self-control, pornography

\section{Introduction}

Access to pornographic content in the digital age is very easy. Based on data from Juniper Research, mobile devices and the internet are the main media for pornographic content providers and around 250 million gadget users access pornographic content [1], until 2015 around 136 billion pornographic videos were accessed through smartphones, with the location of accessing the most pornographic videos was the United States and Western Europe [2]. Statistically, it was found that cyber pornography accessors increased from 2015 and they are expected to continue to increase afterward [3]. A world-famous pornography site named Pornhub checks its site visitors who access pornographic content. It was found that there were 28.5 billion visitors in 2017, which means 81 million visitors per day [4].

Lots of content accessors of cyber pornography have become a big problem for the world community that attacks adults, adolescents, children, couples, families, and society [5]. 
Problems in adolescents to adulthood are often found because they cause problematic sexual development and the risk of depression. Harper and Hodgins's [6] study found that students who experience addiction to internet pornography in Canada cause low psychosocial functions, such as anxiety, depression, life satisfaction, relationship satisfaction, and addiction.

In 2017, Firmansyah [7] wrote in the last 10 years Indonesia's ranking as access topornographic content has continued to increase. At present Indonesia is ranked second in the world as much as 457 percent, after Turkey with a number reaching 657 percent. According to data released by the Pornhub website, the majority of connoisseurs of pornographic content services came from the ages of 18 to 24 as much as $36.3 \%$, aged 25 to 34 years as much as $29.8 \%, 35$ to 44 years have as much as $16.5 \%$ users [8].

The range of ages 18 to 24 is a youth that is filled with passion for self-exploration and experimentation with values and sexual behavior. Therefore pornography is prevalent among students [9]. This is also in accordance with the results of a survey conducted by the researchers on 133 students of Islamic Higher Education in the city of Yogyakarta in January 2019. From the survey, it was found that $75.9 \%$ of students had accessed pornography sites and $55.6 \%$ enjoyed pornographic material presented by the site. A total of 37 students explained the reason they became consumers of pornography, namely to satisfy sexual desires but they do not have to intercourse.

Based on the research of Nelson et al. [10] found that indirectly all religious youth realize that pornography is something wrong, but still use it. According to further explanation by Nelson et al [11], pornography can be a problem in the lives of developing adults because there is a contradiction with the beliefs held, namely the values of religiosity that is believed. Students who also have an age range toward adulthood, especially those studying at Islamic colleges will be formed according to their visions, missions, and strong Islamic values. The average Islamic university in Yogyakarta has a similar vision, namely becoming a university that upholds Islamic values in the application and development of science. This means that Islamic universities are committed to developing their students to become students who benefit the community, master Islamic knowledge and are able to apply Islamic values in providing benefits to the wider community, in addition to being knowledgeable and highly skilled in science and technology. Thus, it is clear that when Islamic university students access pornography, it deviates from the vision, mission, and values embraced by higher education institutions.

The spread of online pornography has caused increased exposure to pornography globally. Pornographic material providers use the internet as a means of serving customers. The internet is open 24 hours a day, 365 days a year. The internet is spread out and can be accessed from various sites [12]. In the Law of the Republic of Indonesia Number 44 of 2008 article 1 paragraph 1 mentioned in Article 4 states that what is meant by pornography is material that explicitly contains intercourse (including deviant relationships), sexual violence, masturbation, nudity or an impressive appearance of nakedness, genitals or child pornography that loosens norms and decency that exist in society. In this recent study, connoisseurs of pornographic services are intended to be related to adult content.

This phenomenon is quite alarming because Indonesia is one of the countries with the most Muslim population in the world. In 2015, it was reported that the percentage of Muslims in Indonesia reached $12.7 \%$ of the world population. Of the 205 million people in Indonesia, it is reported that at least $88.1 \%$ of the population is Muslim [13].

Islam itself has clearly prohibited pornography. This is stated in the Qur'an Surah AnNur paragraph 30-31 Which reads 
"Say to men who believe: Let their gaze be kept safe, and their genitals; ... Say to a woman of faith; Let their gaze be kept safe, and their genitals, and let them not show their jewelry, except those which (usually) appear from it...." (Surah AnNur [24: 30-31])

The verse explains that Allah has forbidden His faithful servants to bow down to what is forbidden. The majority of Ulama argue that what are forbidden to be seen are genitalia[14].

Religion is a reason for individuals to claim that pornography is the wrong thing. Generally, those who are religious will tend to avoid pornography because of religious and moral beliefs [15]. But in fact, it is based on the surreal results that the researchers did and have been explained on the previous page that there are students of Islamic Universities in the city of Yogyakarta who become pornographic consumers.

In religious groups, belief in religion can prevent the use of pornography. Whereas in the religious group exposed, they will feel higher psychological pressure compared to individuals who access pornography but do not have beliefs that are contrary to their behavior [16]. Men who have religious beliefs that oppose pornography but still access pornography are far more likely to feel depression, low self-esteem, confusion of identity compared to religious men who do not access pornography [17]. This conflict arises when individuals consider their behavior immoral, inappropriate and not in accordance with their beliefs [18].

In Al-Ghazali's view, the completeness and tranquility of the soul is a stable, permanent and permanent achievement. This stability of peace of mind is an achievement that needs to be sought to achieve. On the other hand, Sigmund Freud as one of the famous figures in psychology explained that the tranquility of the soul is derived from the harmony of the human psychic mechanism. Humans are said to be sick if they experience internal conflicts within themselves [19]. Reviewing the opinions of the two figures above, it can be seen if the peace of mind and health are a condition where there is no internal conflict and to achieve it requires an effort. it is this inner calm and healthy condition that is difficult for students of Islamic Higher Education to access pornography. There is inner turmoil due to the difference between adopted beliefs and behaviors.

One effort to achieve peace of mind is to draw closer to God and do goodness as old as the religious orders by avoiding immorality [20].

"(To the righteous it will be said), 'O reassured soul. Return to your Lord, wellpleased and pleasing (to Him), and enter among My (righteous) servants and enter My Paradise'." (Surah Al-Fajr [89: 2730])

Samman [21] found that when a person adheres to a value, then there are other values that are also related to him but contrary to the principles held, it will lead to conflict which can cause disruption of subjective well-being. This internal conflict will also cause anxiety, then Dush and Amato [22] emphasized that someone who often experiences negative emotions such as anger and anxiety and dissatisfaction in his life is a characteristic of people who have low subjective well-being.

Subjective well-being is an individual's assessment of his life. This assessment can be primarily a cognitive assessment, or consists of the frequency of someone experiencing pleasant or unpleasant emotional experiences [23]. Diener [24] added that subjective wellbeing is a situation that refers to the fact that individuals objectively believe that their life is something that is desirable, pleasant, and good.

Overall subjective well-being is an assessment of the quality of internal human experience and basic aspects of life such as social contact, family relationships, daily activities, thoughts, self-esteem, stress management patterns, and health in the spectrum from positive to negative [25]. In line with the thoughts of Michael, Sarah, and Peter [26] and Ningsih [27] which stated that subjective well-being is self-evaluation that leads to life satisfaction (cognitive) and the 
balance between positive emotions and negative emotions (affective) to the whole life. Subjective well-being is also defined as a positive state of mind that covers all life experiences, including life satisfaction and happiness [28].

The aspects of subjective well-being according to Diener et al [29] are cognitive aspects (life satisfaction) and affective aspects (the existence of positive affect and low negative affect). Based on these aspects, it can be seen that there are still low subjective well-being in students due to pornographic consumption behavior, such as the emergence of feelings of regret, shame, and various other negative affections. Thus, it can be concluded that subjective well-being is a person's evaluation of his life experience, characterized by pleasant feelings and low negative feelings.

Self-control and repentance are one of the factors that can influence subjective well-being. Selfcontrol makes someone can avoid deviant behavior [30] and help individuals to reduce aggression by considering aspects of the rules and social norms that apply [31]. Thus, it can be said that self-control can be a shield to avoid the temptation to commit deviant behavior that it can return to the right action, reinforced by the statement of Ajzen [32] which stated that there is a relationship between self-confidence and self-control. The higher the self-confidence, the more controlled the behavior because it aims to achieve the intended behavior. It also includes controlling remorse for deviant behavior that has been done. Self-control is the ability of individuals to rule out or change inner reactions, either stopping unwanted behavior or refraining from acting in this way [33].

The more a person is able to control himself, the more process of repentance, according to Al-Jauziyah [34] started from regretting having made a deviation, there is an effort to stop the deviation and determined not to repeat it again will become easier. Someone who has good control of his life is more able to control the meaning of each experience in his life including a pleasant experience or not. Therefore, it can be concluded repentance and good selfcontrol abilities are needed to change negative meanings to be positive in someone's life. Husain [35] describes repentance as one of the values in the Qur'an that can be used as a way to overcome the pressures in life. Repentance is one of the ways in Islamic psychotherapy that is used as spiritual refreshment and develops the potential that is within, through the process of repenting someone has self-awareness to change bad behavior, evaluate theirselves, and change behavior consistently in a positive direction [36]. That is in line with Ubaidillah (2014) research that repentance helps someone to heal with their sickness.

This recent study is different because it conducted research on the concept of repentance by using quantitative research methods. Several previous studies [37] conducted research on the concept of repentance using experimental methods or literature review. In addition, this study also produces a new measuring instrument used to measure the concept of repentance.

The purpose of this study is to know the relationship between repentance and subjective wellbeing of Muslim college students in Yogyakarta who access pornographic sites, and selfcontrol as a moderator between them. The hypothesis in this study is that there is a relationship between repentance and subjective well-being of Muslim college students in Yogyakarta with the moderator of self-control.

\section{Methods}

This research is a quantitative research. Repentance is the independent variable, subjective well-being is the dependent variable, and self-control is the moderator variable. 


\subsection{Subjects}

The population in this study were active Undergraduate students of Islamic Universities in Yogyakarta who were consumers of cyber pornography. The sampling technique was purposive sampling, with the characteristics of the research subject, bachelor degree at Islamic universities in Yogyakarta; male and female; with ages ranging from 17 to 25 years; consumers of cyber pornography. The researchers obtained a sample of 102 subjects.

\subsection{Data Collection Method}

The data collection method used instrument of repentance, subjective well-being, and self-control.

\subsubsection{Subjective Well-being Scale}

The researchers adapted a measure of subjective well-being based on aspects expressed by Diener et al. [38], namely; aspect of cognitive and affective aspects. The measuring instrument adapted is the Satisfaction with Life Scale (SWLS) by Diener, Lucas, \& Oishi [39] as a measure of cognitive aspects. SWLS consists of 5 items with 7 alternative answers (strongly disagree to strongly agree). The reliability of the SWLS measurement is 0.819 . The researchers also adapted the Positive Affect and Negative Affect Scale (PANAS) measure by Watson, Clark, and Tellegen [40] as a measure of affective aspects. PANAS consists of 20 items which divided into 10 positive affective items and 10 negative affect items with 5 alternative answers (very rare to very frequent). The reliability of the PANAS measurement in positive affect is 0.797 and the negative affect is 0.877 . The calculation of the total score for the subjective welfare variable is to change the score to a standard score and the sum of the two scales, using the formula SWLS + (PANA).

\subsubsection{Self-control Scale}

The researchers adapted the Self-Control Scale Brief Version self-control tool (SCS Brief) developed by Tangney, Baumeister, and Boone [41]. The aspect of self-control is selfdiscipline, deliberate/nonimpulsive, healthy habits, work ethic, and reliability. The SCS Brief consists of 13 items with 6 alternative answers (very inappropriate to very suitable). the reliability of the SCS Brief measurement is 0.692 .

\subsubsection{Repentance Scale}

Measurement of repentance variables using a measuring instrument developed by the researchers namely the Repentance Scale. Repentance Scale Developed based on repentance aspects expressed by Al-Jauziyyah [42]; aware of mistakes that have been made, regret those mistakes, stop completely from similar mistakes, and commit not to repeat them in the future. The Repentance Scale consists of 18 items with 6 alternative answers (very inappropriate to very suitable). The reliability of the Repentance Scale measurement is 0.841 .

\subsection{Research Design}


The design used in this study is correlational, namely looking at the relationship between independent variable and dependent variables. This type of research is included in quantitative research and the data is in the form of numbers that will be obtained by statistical methods. The quantitative method was used to see the significance of the relationship between independent variables and dependent variables [43]. After that, we used multiple regression analysis to find out selfcontrol as a moderator between repentance and subjective well-being. Self-control as a moderator will strengthen the relationship between repentance and subjective well-being.

\subsection{Analysis Method}

The data obtained from this study will be analyzed using multiple correlation analysis, namely bivariate analysis with Pearson Correlation, to see whether there is a relationship between independent and dependent variables. Furthermore, an analysis was performed using multiple regression test technique to find out whether self-control was a moderator. Selfcontrol is said to be a moderator variable when selfcontrol strengthens the relationship between repentance and subjective well-being.

\section{Results}

The assumption test was carried out in the form of a normality test and a linearity test. Normality test was using the Kolmogorov-Smirnov test, the results of the three variables were normally distributed with repentance significance value $\mathrm{p}=0.165(\mathrm{p}>0.05)$, Self-control $\mathrm{p}=$ $0.200(\mathrm{p}>0.05)$, and Subjective Wellbeing $\mathrm{p}=0,060(\mathrm{p}>0,05)$.

Table 1. Person Correlation.

\begin{tabular}{lcc}
\hline \multicolumn{1}{c}{ Variable } & Correlation & Sig \\
\hline $\begin{array}{l}\text { Repentance }- \text { Self- } \\
\text { control }\end{array}$ & $0,505^{* *}$ & 0,000 \\
Repentance -- SWB & $0,366^{* *}$ & \\
Self-control -- SWB & $0,574^{* *}$ & 0,000 \\
\hline
\end{tabular}

The statistical technique used to know the relationship between repentance, self-control, and subjective well-being is the Pearson bivariate correlation technique. Based on Table 1, it can be seen the results of the correlation between repentance and self-control are $\mathrm{r}=0.505 \mathrm{p}$ $<0.001$, Subject repentance and well-being are $\mathrm{r}=0.366 \mathrm{p}<0.001$, Self-control and Subjective Wellbeing are $r=0.574 \mathrm{p}<0.001$. Thus it can be interpreted that there is a significant relationship between repentance, self-control, and subjective wellbeing. Because $r$ count or Pearson Correlations in this analysis is positive, it means that the relationship between the three variables is positive or it can be said that the increasing repentance and self-control will also increase Subjective Well-being.

The next analysis was using multiple regression analysis techniques. It was found that self-control as a moderator between repentance and subjective well-being. In table 2, it is seen 
that the value of $\mathrm{R}$ square between repentance and subjective wellbeing is 0.314 , then after adding self-control the value of $\mathrm{R}$ square rises to 0.339 . Then it can be concluded that the existence of Self-control will be able to strengthen the relationship of repentance to Subjective Well-being.

Table 2. Multiple Regression Analysis.

\begin{tabular}{lc}
\hline \multicolumn{1}{c}{ Variable } & R Square \\
\hline Repentance - SWB & 0,134 \\
Repentance - SWB - through Self-control & 0,339 \\
\hline
\end{tabular}

\section{Discussion}

Based on the results of this research, it was found 102 students of Islamic universities who access pornography and 73 students admitted to enjoying the content. The value of Islam for pornography is one prohibition that must be abandoned. In Hadith of Muslim 2553, Rasulullah SAW said that sin is something that feels disturbing to the soul and does not want to be revealed to others. In some cases, someone who consciously commits a sin will try to hide mistakes and resulting in prolonged stress. The psychological impact that arises because of the sins committed in the form of unsettling feelings will result in mental health disorders in the individual [44]. The occurrence of psychological conflict causes anxiety. However, someone who has good self-control will be able to hold himself back from committing sins that it becomes easier to be happy because he is better able to control and manage internal and external conflicts properly. Self-control will direct individuals to avoid negative things and lead to more positive things, one of which is to repent of deviant behaviors [45]. The effort of an individual who has committed a sin to return to his natural state in a healthy mental state is to do repentance [46]. Repentance is an independent effort by an individual to break away from feelings of guilt and self-desire to make things better [47].

Bergin [48] said that repentance requires self-control. Self-control carried out by repentant people demands that the person abandons sin, and will develop a new lifestyle that contains selfregulation to be better in the future. In harmony with one dimension to achieve perfect repentance according to Ilyas (2001), which is to cover up past mistakes by multiplying good deeds because they can erase past sins. Rusdi [49] found that the effort to abandon sin and deviant deeds had a significant correlation with peace of mind, where peace of mind could not be obtained without an attempt to leave evil. The peace of mind gained from the repentance process is carried out will improve individual welfare [50].

The study in line with the results of this recent study that there is a positive relationship between self-control, repentance, and subjective well-being, if individuals increasingly have self-control and repent, then the subjective well-being of the individual will increase, and vice versa. The results of this study support the opinions expressed by Corey [51] that religion is one of the potential possessed by individuals that can be used in the therapeutic process.

Based on 133 responses received by researchers, it is known that $76.3 \%$ which is 102 respondents still access pornography. From 102 respondents found $74.5 \%$ has subjective wellbeing in the low and medium categories. This means that most respondents do not have subjective well-being. This happens because of psychological conflicts caused by inconsistencies between religious beliefs and behavior [52], thus the repentance process 
formulated by Al-Jauziyyah [53], such as regretting deviant behavior, stops making the same mistakes, and is determined not to repeat it again cannot be done to the maximum.

There are some limitations of this research, such as the number of respondents and limited literature. The first limitation, namely the number of respondents who are still few and only limited to the scope of Yogyakarta, even though the problems raised are a broad problem, so for the next researcher should increase the number of respondents and expand the range of research. The second limitation is that the literature on repentance is limited, so the researchers suggest more research is needed in this field. There are also some suggestions for future researchers, namely to try to develop this research in the context of religions other than Islam. In addition, the next researcher can examine the effective contribution of the influence of self-control and repentance on subjective well-being. The next researcher can try to associate this variable with other variables such as anxiety. In addition, further researchers are expected to use a higher number of samples and also try to be studied in other areas outside the city of Yogyakarta.

\section{Conclusion}

Based on the results, it is known that there is a positive relationship between repentance, selfcontrol, and subjective well-being for Muslim college students in Yogyakarta, which means that the hypothesis is accepted. Subjective well-being increases when repentance increases and self-control strengthens the relationship. These results are expected to be the basis of further research in knowing the extent to which the influence of repentance behavior and self-control on the subjective well-being of individuals.

\section{References}

[1] Ozal. 250 juta pengguna tablet akan mengakses pornografi. Jagatreview. Accessed in May $19^{\text {th }}$, 2019. from www.jagatreview.com. (2013).

[2] Suahman, R. Riset: Ada 13 miliar video porno yang ditonton via smartphone. Enciety.co. Accessed from http://www.enciety.co/riset-ada136-miliar-video-porno-yang-ditontonviasmartphone/, in May $19^{\text {th }}$, 2019. (2015).

[3] Pelletier, R. 2015 porn stats show alarming trends. Church Militant. Accessed from https://www.churchmilitant.com/news/article/2015 -porn-stats-show-alarming-trends1, in May 20 ${ }^{\text {th }}, 2019$. (2016).

[4] Nana, D. Pengakses Situs Porno Lewat Smartphone Ternyata Didominasi Kaum Hawa. Retrieved on January $8^{\mathrm{th}}, 2018$, from Malang Times: https://www.malangtimes.com. (2018, December).

[5] Webroot. Internet pornography by the numbers; A significant threat to society. Webroot Smarter Cybersecurity. Accessed in May 20 ${ }^{\text {th }}$, 2019. from www.webroot.com. (2018).

[6] Harper, C. \& Hodgins, D.C. Examining correlates of problematic internet pornography use among university students. Journal of Behav Addict, 5, 2, 179-191. (2016).

[7] Firmansyah, T. Sungguh Miris, Indonesia Pengakses Porno kedua di Dunia. Accessed in January $8^{\text {th }}$ 2019. from Republika: https://nasional.republika.co.id. (2017, December).

[8] Nana, D. Pengakses Situs Porno Lewat Smartphone Ternyata Didominasi Kaum Hawa. Retrieved on January $8^{\mathrm{th}}, 2018$, from Malang Times: https://www.malangtimes.com, (2018, December).

[9] Nelson, L. J., Padilla-Walker, L. M., \& Carroll, J. S. "I Believe It Is Wrong But I Still Do It". American Psychological Association, 136-147. (2010). 
[10] Nelson, L. J., Padilla-Walker, L. M., \& Carroll, J. S. "I Believe It Is Wrong But I Still Do It". American Psychological Association, 136-147. (2010).

[11] Nelson, L. J., Padilla-Walker, L. M., \& Carroll, J. S. "I Believe It Is Wrong But I Still Do It". American Psychological Association, 136-147. (2010).

[12] King, T.R. The Moderating Effect on The Link Between Pornography Use and Negative Outcomes. Dissertation. Liberty University. (2014).

[13] Indrawan, A. Inilah 10 Negara dengan Populasi Muslim Terbesar di Dunia. Accessed in January 8th 2019 from Republika: www.repubika.ac.id. (2017, Mei).

[14] Ad-Dimasyqi, A.I.A. Tafsir Ibnu Katsir Jilid 6. Jakarta: Niaga Swadaya. (2005).

[15] Nelson, L. J., Padilla-Walker, L. M., \& Carroll, J. S. "I Believe It Is Wrong But I Still Do It". American Psychological Association, 136-147. (2010).

[16] Grubbs, J., Sessoms, J., Wheeler, B., \& Volk, F. The Cyber-Pornography Use Inventory: The Development of a New Assesnt Instrument. Sexual Addiction and Compulsivity, 106-126. (2010).

[17] King, T.R. The Moderating Effect on The Link Between Pornography Use and Negative Outcomes. Dissertation. Liberty University. (2014).

[18] Nelson, L. J., Padilla-Walker, L. M., \& Carroll, J. S. "I Believe It Is Wrong But I Still Do It". American Psychological Association, 136-147. (2010).

[19] Syakur, A. Metode ketenangan jiwa: suatu perbandingan antara al-ghazali dan sigmund freud. Islamica, 1(2), 162-173. (2007).

[20] Saripah, T. Mulyana, Y., \& Kamaludin, U.A. Fungsi Zuhud Terhadap Ketenangan Jiwa (Studi Analisis Tafsir Jailani Karya Abd al-Qadir Jailani) Al Bayan. Jurnal Studi Al-Qur'an dan Tafsir, 2, (2). 132-146. (2017).

[21] Samman, E. Psychological and subjective well being: A proposal for internationally comparable indicators. Article. University of Oxford: OPHI Working Paper Series. (2007).

[22] Dush, C.M.K., \& Amanto, P.R . Consequences of relationship status and quality for subjective well-being. Journal of Social and Personal Relationships, 22, 607- 627. (2005).

[23] Diener, E., Suh, E., \& Oishi, S. Recent finding on subjective well-being, 24, 25-41. (1997).

[24] Diener, E. Assessing subjective well-being: Progress and opportunities. Social Indicators Research Series 39, (10), 1-25. (2009).

[25] Sharon, M. \& Hamama, L. Posttraumatic growth and subjective well-being among caregivers of chronic patients: A preliminary study. Springer, 1717-1737. (2013).

[26] Michael, J., Sarah, W., \& Peter, B. Overestimated relationship with subjective well-being. Canadian Psychology, 52, 60-65. (2011).

[27] Ningsih, D.A. Subjective well being ditinjau dari faktor demografi (status pernikahan, jenis kelamin, pendapatan). Jurnal Online Psikologi, 1, 581-603. (2013).

[28] Cummins, R.A., Mellor, D., Stokers, M.A. \& Lau, A.LD. The measurement of subjective well being. Rehabilitation and health assessment, Springer, 409-426. (2010).

[29] Diener, E., Suh, E., \& Oishi, S. Recent finding on subjective well-being, 24, 25-41. (1997).

[30] Bolin, A.U. Self-control, perceived opportunity, and attitudes as presictors of academic dishonesty. The Journal of Psychology, 138, (2), 101-114. doi:10.3200/jrlp.138.2.101-114. (2004).

[31] Denson, T.F., DeWall, C.N., \& Finkel, E.J. Self-control and aggession. Current Directions in Psychological Science, 21, (1), 20-25. doi: 10.1177/0963721411429451. (2012).

[32] Ajzen, I. The theory of planned behaviour: Reactions and reflections. Psychology and Health, 26, (9), 1113-1127. doi:10.1080/08870446.2011.613995. (2011).

[33] Tangney, J.P. Baumeister, R.F. \& Boone, A.L. High Self Control Predict Good Adjusment. Less Patholoy, Better Grades, and Interpersonal Succes. Journal Of Personality, 2 272-322. (2004).

[34] Al-Jauziyah, I.Q. Ensiklopedia Taubat (Dari Dosa Menuju Taubat). Depok: Keira Publishing. (2014). 
[35] Husain, S.A. Religion and mental health from the muslim perspective. Handbook of Religion and Mental Health. San Diego: Academic Press. (1998).

[36] Susanto, D. Psikoterapi religious sebagai strategi dakwah dalam menanggulangi tindak sociopatic. Konseling Religi, 4, 15-32. (2013).

[37] Shohib, M. Taubat sebagai metode dasar psikoterapi. Disampaikan pada seminar psikologi dan kemanusiaan di Universitas Muhammadiyah Malang. (2015).

[38] Diener, E., Suh, E., \& Oishi, S. Recent finding on subjective well-being, 24, 25-41. (1997).

[39] Diener E, Lucas, R.E, \& Oishi, S. Subjective WellBeing: The Science of Happiness and Life Satisfaction. Dalam CR Snyder \& SJ Lopez (Ed.), Handbook of positive psychology. New York: Oxford University Press. (2002).

[40] Watson, D., Clark, L.A., \& Tellegen, A. Development and Validation of Brief Measures of Positive and Negative Affect: The PANAS Scales, Journal of Personality Social Psychology, 54, (6), 1063-1070. (1988).

[41] Tangney, J.P. Baumeister, R.F. \& Boone, A.L. High Self Control Predict Good Adjusment. Less Patholoy, Better Grades, and Interpersonal Succes. Journal Of Personality, 2 272-322. (2004).

[42] Al-Jauziyah, I.Q. Ensiklopedia Taubat (Dari Dosa Menuju Taubat). Depok: Keira Publishing. (2014).

[43] Hadi, S. Metodologi Riset. Yogyakarta: Pustaka Pelajar. (2015).

[44] Shohib, M. Taubat sebagai metode dasar psikoterapi. Disampaikan pada seminar psikologi dan kemanusiaan di Universitas Muhammadiyah Malang. (2015).

[45] Khan, A., \& Qureshi, A.M. Can self-control influence subjective well being in life? A study assessing the dynamics and association between the constructs. JISR-MSSE, 13, (2), 23-34. (2015).

[46] Shohib, M. Taubat sebagai metode dasar psikoterapi. Disampaikan pada seminar psikologi dan kemanusiaan di Universitas Muhammadiyah Malang. (2015).

[47] Yulianti, E.R. Tobat sebagai kajian psikoterapi (kajian psikoterapi islam). Syifa AlQulub. 132141. (2017, Januari).

[48] Bergin, A.E. Psychology and Repentance. Speeches.byu.edu. Publication Article. Brigham Young University, 1-7. (1994).

[49] Rusdi, A. Efektivitas shalat taubat dalam meningkatkan ketenangan hati. Psikis, 2, 94-116. (2016).

[50] Kumala, O.D., Kusprayogi, Y., \& Nashori, F. Efektivitas pelatihan dzikir dalam meningkatkan ketenangan jiwa pada lansia penderita hipertensi. Psympathic, 4, (1), 55-66. (2017).

[51] Corey, G. Integrating spirituality in counseling practice, Article 25 Vistas, American Counseling Association. (2016).

[52] Grubbs, J., Sessoms, J., Wheeler, B., \& Volk, F. The Cyber-Pornography Use Inventory: The Development of a New Assesnt Instrument. Sexual Addiction and Compulsivity, 106-126. (2010).

[53] Al-Jauziyah, I.Q. Ensiklopedia Taubat (Dari Dosa Menuju Taubat). Depok: Keira Publishing. (2014). 